\title{
Assessing the Effectiveness of Settling Indonesian Sea Border Disputes through Litigation and Non-Litigation Paths
}

\author{
Nur Arissa Izzati, Chusnul Qotimah Nita Permata, Miftah

\section{Santalia} \\ 1Faculty of Law, UiTM Malaysia, ${ }^{2}$ Faculty of Law, Semarang State University, ${ }^{3}$ Faculty of Law, \\ Semarang State University \\ 1Jl. Sarjana 1/2, Shah Alam, Selangor, Malaysia 40450 \\ 2Jl. Kampus Timur, Sekaran, Gunung Pati, Semarang City, Central Java 50229
}

Article Info: $\quad$ Submitted April 12, 2020 Accepted April 26, 2020

Published May 9, 2020

\begin{abstract}
s :
The Border disputes between sea, island and the state are matters of international courts through the role of international law. Sea boundary problems often occur such as disputes between Indonesia and Vietnam in the Natuna Sea region, disputes over the Exclusive Economic Zone (EEZ), disputes between Indonesia and Malaysia in the Malacca Strait, South China Sea Disputes, etc. Unilateral claims cause relations between countries experiencing conflict. This happens because negotiations between countries have not been completed, violations by disputed countries, unclear sea boundaries, etc. The United Nations Convention on the Law of the Sea (UNCLOS) 1982 is an international maritime law that only applies to ratify countries that can apply it. Settlement can be done through two channels, that are litigation and non-litigation, ITOLS is the last attempt at completion of the litigation path.
\end{abstract}

Keyword: Boundary Dispute, Litigation, Non-Litigation
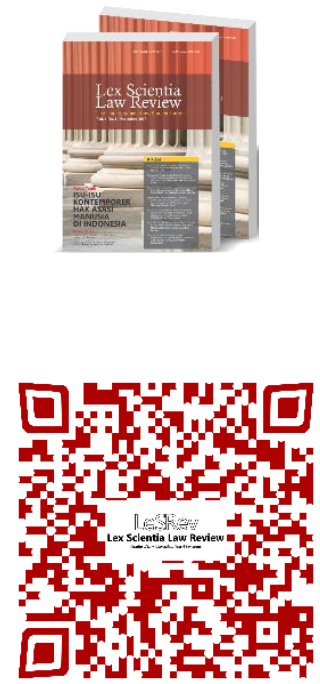

Vol. 4, No. 1

Month May Year

2020

\section{Abstrak:}

Sengketa perbatasan antara laut, pulau, dan negara merupakan urusan pengadilan internasional melalui peranan hukum internasional. Permasalahan batas laut sering terjadi seperti sengketa Indonesia dan Vietnam di wilayah Laut Natuna, sengketa batas Zona Ekonomi Eksklusif (ZEE), perselisihan Indonesia dan Malaysia di Selat Malaka, Sengketa Laut Cina Selatan, dll. Klaim sepihak menyebabkan hubungan antar negara mengalami konflik. Hal ini terjadi karena negosiasi antar negara belum selesai, adanya pelanggaran oleh negara bersengketa, batas laut tidak jelas, dll. Konvensi PBB tentang Hukum Laut (UNCLOS) 1982 adalah hukum maritim internasional yang hanya berlaku bagi negara yang telah meratifikasi yang dapat menerapkannya. Penyelesaian dapat dilakukan melalui dua jalur yaitu litigasi dan non-litigasi, ITOLS merupakan upaya terakhir penyelesaian dari jalur litigasi.

Kata Kunci : Sengketa Batas Laut, Litigasi, Non-Litigasi

\section{Citation :}

Izzati, N.A, Permata, C.Q.N, Santalia, M. (2020). Assessing the Effectiveness of Settling Indonesian Sea Border Disputes through Litigation and Non-Litigation Paths. Lex Scientia Law Review 4(1), 1-18. doi: https://doi.org/10.15294/lesrev.v4i1.38261 



\section{Introduction}

The Republic of Indonesia is an archipelago that has a lot of diversity and natural wealth. NKRI has natural resources not only on land but also in territorial waters also has a great diversity of natural resources included in Indonesia's natural wealth. Indonesia is an archipelago with a total of 17,499 islands with territorial waters reaching 5.8 million $\mathrm{km} 2$, and a coastline length of $81,900 \mathrm{~km} 2 .^{1}$ Indonesia is a country flanked by ten countries, which are Singapore, Australia, Timor Leste, Papua New Guinea, Palau, Philippines, Vietnam, Thailand, Malaysia, and India. Indonesia has two-thirds of the sea area and only three land borders and the rest are sea borders. Indonesia has 10 sea borders including 10 countries including Malaysia, Singapore, the Philippines, India, Thailand, Vietnam, the Republic of Palau, Australia, Timor Leste and Papua New Guinea. While the land borders as a whole there are 3 countries Malaysia, Papua New Guinea and Timor Leste with a land border length of $2914.1 \mathrm{~km}$.

The state has elements in the form of population, sovereign government and territory. In this case the region is important to implement sovereignty and a concept in showing the supremacy of a state that requires territory. Indonesia is an archipelagic country divided into territorial waters and land; the state must be able to secure the region in order to maintain the integrity of the Republic of Indonesia under the 1945 Constitution of the 4th century. ${ }^{2}$ To safeguard the sovereignty and integrity of the country, efforts should be made to protect the outermost regions that border directly with neighboring countries. Indonesia needs a border management system in both sea and land borders so that an organized and professional border management system can be realized.

The boundaries of the Indonesian maritime territory with neighboring countries are territorial sea boundaries, additional zone boundaries, watershed, and continental shelf boundaries. Territorial sea is a region of coastal sovereignty which includes air, sea space and the land beneath it as far as 12 nautical miles from the measured baseline. Additional zones are areas of marine waters up to 12 nautical miles outside the territorial sea or 24 mile baselines. EEZ is a region of marine waters outside and adjacent to territorial seas that are more than 200mil wide from the baseline, where the state has the sovereign right to explore, conserve, and utilize natural resources.

The Border between countries directly related to the state of Indonesia often seems to arise problems related to sea and land boundaries. Indonesia has ten neighboring countries, bordering Singapore, Malaysia, India, Thailand, Vietnam, the Philippines, Papua New Guinea, Australia, Palau, and Timor Leste. The country that lives side by side cannot be separated from various border issues such as smuggling, illegal fishing, terrorism, resource extraction, and even many fishermen from various countries who were arrested for violating the borders of the sea territory of other countries.Borders are important for Indonesia. Borders are always associated with defense, sovereignty, and national security. In this case, it is said to be important because borders are territorial boundaries which have an influence on national defense. Within the territorial borders the state has sovereign rights such as exploring and exploiting natural resources both on the continental shelf boundary, EEZ, and additional zones as stated in article 77 paragraphs 1 of UNCLOS.

The United Nations (UN) held a Convention on the Law of the Sea because it saw the increasingly advanced and increasingly rapid development of marine technology, such as seabed mining technology and the underlying land that has reached at great distances and depths, fishing using modern technology, etc. This makes countries claim one another and compete in controlling the seas to exploit their natural

\footnotetext{
${ }^{1}$ Hassanudin Z. Abidin, et al. (2005). Geodetic Datum Indonesia-Singapore Maritime Boundary: Status and Problems. Bandung: PROC. ITB Science \& Tech, 37 A (1), p. 23.

2 Miriam Budiardjo. (2008). Fundamentals of Political Science. Jakarta : PT Gramedia Pustaka Utama. p.51.
} 
resources. ${ }^{3}$ That claim is what raises problems with the maritime boundaries of countries. Because there are unilateral claims made by world countries, this is a result of the lack of clarity of international sea law governing issues related to maritime boundaries between countries. The law of the sea is the United Nations Convention on the Law of the Sea of 1978 and 1960. Problems and uncertainties concerning the law of the sea form the basis for the holding of the third United Nations Convention. The result of the convention was the birth of the 1982 UNCLOS (United Nations Convention on The Law of the Sea) which was signed on December 10, 1982, at these convention new territorial waters emerged, the Exclusive Economic Zone (EEZ). ${ }^{4}$

Indonesia has begun to discuss issues related to maritime disputes and their resolution. In this case, there are two solutions through litigation and non-litigation. In which, Indonesia is a member of the United Nations and ratified UNCLOS 1982 in The Act Number 17 of 1985 concerning Ratification of UNCLOS, so that Indonesia is subject to the relevant regulations therein. ${ }^{5}$ The United Nations Convention on the Law of the Sea (UNCLOS) 1982 regulates international maritime law, which regulates differences in the demarcation of coastal and the island states. A country's territorial sea is 12 miles, an additional 24-mile zone, and a 200-mile exclusive economic zone measured from the baseline. The boundaries of an island nation are lines connecting points drawn perpendicular to the outermost islands or outermost points of a country. While the state border of the coast is a parallel line between the curves of the coast. Measurement of distance in measuring the coastline is when the coastal water has receded.

Problems arise in the borders between countries related to maritime boundaries, such as conflicts between Indonesia and Vietnam in claiming the Natuna Sea boundary, disputes that occur in the Malacca Strait between Indonesia and Malaysia, disputes that occur in the South China Sea, and so on. This is due to the lack of attention from the government towards surveillance, borders so that many problems arise in the border area that threatens a nation's disintegration. The conflict can also result in countries around the territory of the conflicting country also experience the effects of the dispute.

In UNCLOS 1982, there are arrangements and settlements in the event of disputes or problems in the sea boundary region, continental shelf area, EEZ, and so on. However, if there are differences of opinion between countries regarding the interpretation of UNCLOS in accordance with article 187 UNCLOS, which explains that disputes between participating countries regarding interpretation or application of this chapter or appendices relating thereto. Therefore, this dispute resolution can be surrenderedat the request of the parties to the dispute to a special international court room for sea law to be established in accordance with attachments VI, Articles 15 and 17 or can also be submitted at the request of one of the parties to the dispute to an adhoc room, a sea floor dispute which will established in accordance with annex VI Article 36. In Chapter XV UNCLOS regulates the settlement of disputes, dispute

\footnotetext{
3 I Wayan Phartiana. (2014). Law of the Sea of Internasinal and Law of the Sea of Indonesia. Bandung: Publisher Yrama Widya, P. 18-19

${ }^{4}$ United Nations Convention (UNCLOS) 1982

${ }^{5}$ Maulidya Yuseini, et al. (2018). Settlement of Sea Disputes Between Indonesia and Malaysia in the Malacca Strait Area According to International Sea Law, Journal of Law Lanterns; University of Negeri Jember, 5 (3), p. 459, do 10.19184 / ejlh.v5i3.7731
} 
resolution is required by peaceful means in accordance with article 279 of UNCLOS. ${ }^{6}$ Although, UNCLOS 1982 has been recognized by 160 countries and 1 organization, the European Community 7 . However, disputes over national boundaries regarding maritime boundaries between member countries can still occur, as a result of different claims between countries over the baselines used. Although in general, sea-border agreements between countries are determined by bilateral negotiations or negotiations, they must comply with the provisions contained in the 1982 UNCLOS. ${ }^{8}$ If, bilateral negotiations and negotiations are unable to resolve this matter then the maritime boundary issue can be submitted to the international court through litigation (ITOLS).

Based on the description above, the authors are interested in studying more deeply and based on the description above, the authors are interested in studying more deeply and analyzing more specifically on the effectiveness of the resolution of the Indonesian sea boundary dispute through litigation and non-litigation.

\section{Research Methods}

The research method used by researchers is the normative legal research method, with the legislation and case approach. Normative research is research aimed at written regulations so that the research is very closely related to the library because this normative law requires primary and secondary data. ${ }^{9}$ In this study using primary and secondary legal materials, primary legal materials include the United Nations Convention on the Law of the Sea 1982, agreements on the determination of maritime boundaries between states and decisions of international courts regarding resolution of sea boundary disputes. The Secondary legal material in the form of national and international publications on international sea law, articles and books that are relevant to this research. The technique of collecting legal materials uses literature and document studies, and is analyzed by identifying facts, interpretations and legal reasoning in a systematic, logical, and juridical manner. ${ }^{10}$

\section{Result and Discussion}

\subsection{Various Settlement Lines}

\subsubsection{Litigation Pathway}

\section{International Court of Juctice (ICJ)}

The International Court of Justice is a court that is generally capable of resolving international disputes. The International Court of Justice is the main judicial institution established by the United Nations (UN) in June 1945 based on the Charter of the United Nations. ${ }^{11}$

\footnotetext{
${ }^{6}$ Kiki Natalia. (2013). Settlement of Boundary Issues Between Inndonesia and Malaysia in the Malacca Strait Waters Viewed from UNCLOS 1982, Calyptra: University of Surabaya Student Scientific Journal, 2 (2), p.10.

${ }^{7}$ Ismi Yulia Masfiani L, Tri Setyawanta R, Nanik Trihastuti.(2016). Settlement of Maritime Border Disputes Between Costa Rica and Nicaragua in the Caribbean Sea and Pacific Ocean In UNCLOS 1982 Perspective, Diponegoro Law Journal, 5 (3), p.5. Retrieved from http; // www.ejournals1.undip.ac.id/index.php/dlr/

9Soerjono And Abdurahman, H. (2003). Legal Research Methods. Jakarta: Rineka Cipta. ${ }^{10}$ Soekanto Soerjono and Mamudji Sri (1990). Normative Legal Research. Jakarta: Rajawali Press ${ }^{11}$ International Court of Justice. Retrieved from : https://www.icj-cij.org/en/court, Accessed on March 282020
} 
The International Court of Justice is domiciled in The Hague of the Netherlands and has countries that are members of the United Nations, which has a role to settle disputes in accordance with international law. The role of this institution is to settle meetings between countries that are members. This institution also provides opinion or advice to official and specialized bodies formed by the United Nations.

In resolving ICJ disputes based on applicable international law, international customs which are evidence of general practice and accepted as law, general principles which are recognized by countries that have civilization. Those who are entitled to submit their cases are the countries whose members are those cases not the case at the request of individuals, non-governmental organizations, corporations or others.

There are several ways to submit a case to ICJ including:

a. Special Agreement (Special Agreement), two or more disputing countries jointly submit the case to the International Court of Justice in the form of an agreement.

b. Special Clause in the Treaty of Agreement (Clause in treaty), the disputing country uses the clauses contained in the treaty which are used by one of the countries to accept the jurisdiction of the International Court of Justice when a dispute or difference in interpretation regarding the application of the treaty.

c. Unilateral Declaration (Unilateral Declaration)

So far, the International Court of Justice (ICJ) has decided many decisions or international problems including Indonesia and Malaysia related to Sipadan Island and Ligitan Island, which in the end the conflict was brought to the International Court of Justice (ICJ) with the agreement of the two countries and the International Court of Justice (ICJ) decided that Sipadan and Ligitan were included in Malaysian sovereignty.

\section{International Tribunal for the Law of the Sea (ITLOS)}

The International Court of Law of the Sea is a judicial body established by the United Nations (UN) to adjudicate a dispute arising from the interpretation and response of the convention. ITLOS is domiciled in Hamburg Germany, with 21 independent members elected and has a high degree of justice and integrity in the field of maritime law.

The Tribunal has jurisdiction over any dispute regarding the interpretation or application of the Convention, and for all matters specifically regulated in other agreements that give jurisdiction to the Tribunal (Statute, article 21). The Tribunal is open to States Parties to the Convention (that is, States and international organizations that are parties to the Convention). It is also open to entities other than State parties, that is, States or intergovernmental organizations that are not parties to the Convention, and to state companies and private entities "in any case expressly provided for in Section XI or in each case submitted in accordance with other agreements which give jurisdiction about the Court accepted by all parties to the case "(Statute, article 20). ${ }^{12}$

12 International Tribunal for the Law of the Sea. Retrieved from : https://www.itlos.org/en/the-tribunal/, Accessed on March 282020. 
Cases that enter ITLOS are cases or disputes that have close links with sea laws such as sea boundaries such as the Exclusive Economic Zone (EEZ), fisheries disputes, and marine environmental disputes. ITLOS is also open to entities other than States parties in any case that is expressly regulated in Part XI of the Convention or in any case filed in accordance with other agreements that give jurisdiction to the Tribunal accepted by all parties to the case (Convention, article 291; Statute, article 20, paragraph 2). ${ }^{13}$

As for countries that have submitted cases to ITLOS, such as the case of Malaysia with Singapore regarding Land Reclamation. ITLOS has the same role and function as the International Court of Justice which is both institutions formed by the UN that can resolve disputes between countries where both countries agree to resolve their disputes through ITLOS. There are advantages in resolving maritime law cases in litigation to ITLOS because ITLOS specifically was formed to resolve cases related to maritime law which certainly concerns the sovereignty of jurisdiction by a country in the EEZ so that, it is fairly time consuming, whereas through the International Court of Justice (ICJ). Certainly, it will take a long time due to having to wait for another case (outside the law of the sea).

\subsubsection{Non-Litigation Pathway}

Conflicts that occur between countries will certainly be a little different in solving problems because conflicts between countries can be said with international disputes. Settlement of cases that occur between countries so far can be through existing judicial mechanisms and institutions such as the International Court of Justice in addition to using the dispute resolution mechanism through arbitration. Settlement of disputes violating marine law has more complex characteristics compared to other international legal disputes because it requires in-depth knowledge and expertise in the field of sea law.

Arrangements governing sea law already exist and are complemented by international conventions, better known by UNCLOS, which certainly becomes positive law in Indonesia because it has been ratified and ratified by Law Number 17 of 1985 concerning Ratification of the United Nations Convention on The Law of the Sea. With the 1982 UNCLOS, an International Tribunal on the Law of the Sea was formed based in Humburg Germany.

In the Charter of the United Nations (UN) regulates the form of international dispute resolution, i.e. peaceful settlement and resolution of violence. Article 33 of the UN Charter mentions that the mechanism is Negotiation, Enqury, Mediation, Conciliation and Arbitration are means of peaceful settlement of international disputes.

International law certainly respects the important role of a country's territory such as respect for the integrity and sovereignty of a country's territory or territorial integrity and soveregnity. Conflict or conflict which is closely related to the sovereignty of a country is a dispute regarding the borders of a country. The boundaries of a country's territory certainly indicate the limits of the end of a country's legal authority and also explain the validity of legal powers for

13 International Tribunal for the Law of the Sea. Retrieved from https://www.itlos.org/jurisdiction/competence/, Accessed on March 282020. 
other countries. ${ }^{14}$ In the division of the sea area or the determination of the boundaries of the sea area known as delimitation. Delimitation is a process that involves setting boundaries between countries, especially sea areas. ${ }^{15}$

This dispute regarding sea boundaries is a matter that is quite alarming for all countries in the world. Many countries of the world worry about the natural resources of the sea they have because at this time the world economy has turned into a resource based in the ocean or the blue economy. Coastal countries are aware of their sea boundaries which are intended to exploit and exploit both minerals and food sources. ${ }^{16}$

According to the law of the sea the territorial sea is 12 nautical miles adjacent zones are 24 nautical miles, and the exclusive economic zone (EEZ) is 200 nautical miles from the base line (UNCLOS 1982, art 3.33 and 57). Every coastal state is becoming very concerned about themine resources because the world economy is turning into the ocean-based resources which are being termed as Blue Economy. So, all these claimed their different maritime zones according to their own interest. Maritime boundary dispute is occurring most due to the overlapping claims between adjacentor opposite states for 12 nautical territorial seas, seas, 200 nautical miles EEZs, and Continental shelves which may extend beyond 200 nautical miles and due to the contesting claims ofsovereignty over the same island or the same area of mainland, eg, Bakassi peninsula in ICJ Cameroonv. ${ }^{17}$

Settlement of maritime disputes or maritime boundaries between countries is an international phenomenon governed by international law. In matters of maritime affairs, the United Nations Convention on the Law of the Sea (UNCLOS 1982) is a specific codification that was announced in 1982 and entered into force in 1994. Article 287 of the United Nations Convention on the Law of the Sea states that when signing, ratifying, acceding, or at any time thereafter, a state shall be free to choose, by means of a written declaration, one or more of the following means for the settlement of disputes concerning the interpretation or application of this Convention:

a) the ITLOS established in accordance with Annex VI,

b) the International Court of Justice (ICJ),

c) an arbitral tribunal constituted in agreement with Annex VII,

d) a special arbitral tribunal constituted in agreement with Annex VIII for one or more of the categories of disputes specified therein (UNCLOS 1982).

In accordance with Article 33 of the UN Charter directing the parties to the dispute for a peaceful settlement in their own way (UNCLOS 1982), and subject to Article 287 UNCLOS, where each state has the right to choose one or more ways to resolve their disputes regarding interpretation and application of this Convention (UNCLOS 1982). Although the United Nations Convention on the Law of the Sea regulates all aspects of sea-based issues, the provisions

${ }^{14}$ Ria Tri Vinata. (2017). Harmonization of Equidistance Line Priciple and Media Lline Principle in Setting Sea Boundaries, Journal of Legal Perspective, 17 (2), p. 218.

${ }^{15}$ Victor Prescott.(2004). Maritime Political Boundaries of the World. Martinus Nijhoff Publisher,. p.245.

${ }_{16}$ Md. Monjur Hasan, He Jian, Md. Wahidul Alam \& KM Azam Chowdhury, 2019, Protracted maritime boundary disputes and maritime laws, Journal of International Maritime Safety, Environmental Affairs, and Shipping, 2 (2), p. 89.

${ }^{17} \mathrm{Ibid}, \mathrm{pp} .90$.

\section{https://journal.unnes.ac.id/sju/index.php/IsIr/}


regarding sea boundaries are not well defined and clear. This convention is aimed at the process of setting boundaries for different maritime zones between countries that are affected by agreements on the basis of international law to reach a just solution.

If the disputing party fails to reach an agreement they are entitled to submit a resolution to the sea boundary dispute in accordance with the procedures in the Sea Law Convention (UNCLOS 1982) stated in section XV of the Convention. There are two types of dispute resolution processes under this Convention, Part 1 of Section XV states non-litigation procedures which constitute negotiation, mediation and conciliation, and Part 2 of Section XV relating to litigation settlement includes ITLOS in Appendix VI, the document, ICJ and the Artbitration Court which was created based on Appendix VII and the creation of a special Artbitration Court formed as a panel of experts.

Legal sources concerning legal principles relating to institutional functions and various forms of borderline technical issues that give rise to rights and obligations in the use, management and guidance, territorial waters are also contained in international law such as:

a. Decision of the international court on fisheries disputes between Britain and Norway in 1951: "international court of justice, norwegian fisheries case: judgment of 18 december 1951"

b. 1958 Geneva Convention: "convention on the territorial sea and the contiguous zone"

c. United Nations Convention on the Law of the Sea in 1982: "United Nations Convention on the Law of the Sea" and reference to the implementation of the provisions on Baselines from 20 countries: "Baselines: An examination of the relevant provisions of the United Nations Convention on the Law of the Sea 18

Territorial boundary agreements between Indonesia and Malaysia in Kalimantan and the Malacca Strait, Indonesia with Singapore in the Singapore Strait, and Indonesia with Papua New Guinea.

\subsection{Problem and Resolution Factors}

\subsubsection{Factors causing disputes}

Disputes over maritime boundaries for island nations are not new, especially regarding the sovereign rights of a country. Especially for Indonesia, which is the largest archipelago in the world, of course, its territory will be bordered by the sea and land with other countries such as Vietnam, the Philippines, Australia, Timor Leste, Papua New Guinea, Brunei Darussalam, and Thailand.

The ocean has abundant wealth, especially natural resources that have both flora and fauna and even energy resources such as natural gas. Utilization of the sea in addition to its natural resources, the sea can be used for international trade routes such as the South China Sea in Southeast Asia which is used as a shipping lane either for trade or for the mobility of people between countries. The factors for the occurrence of zinc between the sea boundaries include: 19

18 Prijanto H. (2007). International Law of the Sea. Malang: Bayumedia Publishing, p. 67.

${ }_{19}$ Merilin LI Thomas. (2013). Juridical Review of Dispute Resolution Regarding the Determination of State Sea Boundaries (Case Study of Ambalat Territory Dispute between Indonesia and Malaysia, Journal: Lex et Societatis, 1 (2), p.160. 
a. Each of the countries that border both Indonesia and other countries claim each other's territorial waters which they recognize as territorial territories,

b. There are no definite state boundaries between countries, especially those concerning sea areas, such as the South China Sea, Natuna Sea and its surroundings,

c. The absence of a clear agreement between countries that claim each other regarding the boundaries of their country,

d. The abundant natural resources contained in disputed sea areas such as natural resources in the form of flora, fauna, oil and gas.

Besides the things above there are also other causes such as:

a. One of the countries violates international law / treaties,

b. One country / party intentionally violates the rights / interests of another country.

c. There are misunderstandings between disputing countries

\subsubsection{Settlement of International Sea Border Disputes}

Under Article 296 paragraph (1) UNCLOS states that any decision made by a court in general or a special court having jurisdiction under Part XV, Part 2 UNCLOS "will be final and be followed by all parties to the dispute." Paragraph (2) of the same Article provides that "each of these decisions has no binding force except between the parties and the parties respecting that particular dispute." Because this Article applies to the decisions of all disputes the settlement bodies "has jurisdiction under Part 2," therefore the award given by the arbitral tribunal based on Annex VII is final and binding on the parties that follow it. 20

It should be remembered in Part XV UNCLOS also mentions that there are two types of solutions, namely through litigation or non-litigation, which can both be used in accordance with the agreement of the countries or parties to the dispute.

\section{a. Non-Litigation}

1) Negotiation

Negotiations are an important and peaceful settlement. These negotiations resolve bilateral or multilateral disputes between countries regarding maritime boundaries or others. (Aceris Law: 2015) in a negotiation is a settlement that is most often done by the disputing countries regardless if the negotiations are stuck later. This negotiation has a great advantage for the parties, meaning that the terms and time of the agreement and the way the agreement is presented are left to the disputing parties. They are free to choose and form what kind of negotiations will be carried out without adnaya forced parties. All things that go through negotiations are not called third parties,

Negotiations become widely chosen by the parties to the dispute because they believe that using litigation will always have a great risk for the parties, besides that the legal scope available is relatively limited than the open opportunity of negotiations which can be said to be easier to reach

${ }^{20}$ Hao Duy Phan, Lan Ngoc Nguyen, 2017, The South China Sea Arbitration: Bindingness, Finality, and Compliance with UNCLOS Dispute Settlement Decissions, Asian Journal International Law, p.2. 
agreement on decisions regarding the country's sea boundary. Statistics show that from 1994 to 201216 negotiations had taken place, and some of them were successful, such as the 2003 Negotiations between Azerbaijan, Kazakhstan and the Russian Federation; 2004 Negotiations between Australia and New Zealand; ZEE Mauritius-Seychelles 2008 Limitation Agreement, and others (Aceris Law: 2015).

Negotiations have also been carried out by Indonesia with Australia on the re-determination of the country's borders in the longest East Sea as set out in the 1997 Perth Treaty. In this Treaty Timor Leste is still a part of the Indonesian State while since 2002 Timor Leste has liberated itself which means that Timor Leste has separated itself from Indonesia and has its own water claims.

This negotiation between Indonesia and the Kangaroo State was because in early 2018 Timor Leste and Australia had agreed to a maritime border treaty between East Timor and Australia through a conciliation commission based on a mechanism under the 1982 Law of the Sea Convention conducted in New York, United States.

This renegotiation between Indonesia and Australia needs to be done carefully because it can also disrupt the long-standing cooperation between the two countries. However, these negotiations have yet to produce results for the continuation. This is different from the negotiations between the Philippines and Indonesia regarding the maritime sea boundary, which is over. Reporting from kemlu.go.id (23/9/2019) Indonesia and the Philippines have completed discussions on the ratification of the EEZ boundaries of the two countries, which subsequently exchanged instruments of ratification had been conducted by the foreign ministers of Indonesia and the Philippines in August 2019 in Jakarta ${ }^{21}$.

2) Mediation

Article 33 of the UN Charter stipulates that mediation is an alternative means of resolving international events. Mediation in resolving a dispute certainly presents a third party which does not favor one of the parties who are in a crowd. Although mediation is a very successful method for resolving international conflicts in matters of maritime boundaries, disputes over the application of other boundaries countries rarely use the use of mediation or good offices. For example in (Aceris Law 2015) mediation of the 2015 OAS Belize-Guatemala Border dispute. This is not yet resolved and asks the parties to take the matter to the International Court of Justice (ICJ).

3) Conciliation

Conciliation is another non-judicial procedure for the peaceful settlement of sea boundaries as stated in Article 284 Section XV of UNCLOS and the conciliation procedure is canceled, discussed in Appendix 15. Because the level of conicilation (peace) relating to sea boundary disputes is very small. Most countries are almost never used, even most states are not interested in making peace over their disputes. The

21 Ministry of Foreign Affairs Republic of Indonesia. Retrieved from : https://kemlu.go.id/portal/id/read/389/berita/indonesia-dan-filipina-have-resolve-ratification-programbatas-zee, Accessed on April 302020. 
1981 Iceland / Norway Continental dispute regarding Jay Mayen Island was one of the conciliations that was recorded until now (UN 1981).

In conciliation the parties to the dispute must submit their own obstacles to the dispute themselves to the third party and the decision may be taken by a third party whose decision has the binding power of the parties. The reason is not much in demand is because it is binding and they are afraid of resolving disputes through conciliation because they do not want to lose.

4) Arbitration

Arbitration is the most popular and successful way to settle sea boundary disputes after the implementation of UNCLOS in 1994. According to Appendix VII of the Law of the Sea Convention, this court consists of 5 arbiters, with each party to the dispute designating an arbitrator and they equally designating the other three. If needed, the President of ITLOS has the authority to appoint the arbiter.

One method of determining the compulsory sea boundary is arbitration. Usually when the parties to the dispute fail to resolve the dispute but it is very necessary to resolve it in order to exploit marine resources, then they will move on to settling this arbitration. Through arbitration many island nations can settle long-term disputes over their maritime maritime boundaries.

In 2014, Bangladesh and India settled their 40-year arithmetic maritime boundary dispute which began in 1974. ${ }^{22}$ In addition there are also a number of maritime boundary disputes that have been resolved through LOSC Annex VII arbitration such as: ${ }^{23}$

a) Australia and New Zealand v. Japan (Southern Bluefin Tuna Arbitration, 4 August 2000)

b) Ireland v. United Kingdom (Mox Plant Arbitration, 6 June 2008)

c) Malaysia v. Singapore (Land Reclamation Arbitration, 1 September 2005)

d) Bardados v. Trinidad and Tobago (Maritime Arbitration Arbitration, 11 April 2006)

e) Guyana v. Suriname (Maritime Restrictions Arbitration, 17 September 2007)

f) Mauritius v. UK (Chagos Kepula Arbitration, 18 March 2015)

g) Argentina v. Ghana (ARA Libertad Arbitration, 11 November 2013)

h) Philippines v. China (South China / West Philippines Sea Arbitration, 12 July 2016)

i) Denmark v, Russian Federation (Atlanta Arbitration Herring Scandinavia, 23 September 2014)

\section{b. Litigation}

\section{1) International Court of Justice}

According to Haula Adolf in (Adolf: 2004) in the settlement of disputes between countries or international disputes, one of the alternatives is to be

22PCA, 2014, The Bay of Bay of Bengal Maritime Boundary Arbitration between the People's Republic of Bangladesh and Republic of India.

${ }^{23}$ Aceris Law, 2015, Law of the Sea Dispute Settlement Mechanism,International Arbitration Attorney Network. Retrieved from https://www.international-arbitration-attorney.com/lawofthe-sea-dispute-settlement-mechanism/, Accessed on April 302020. 
settled under an international judicial body, which is the International Court of Justice. International Court of Justice (International Court of Justice) is a chart or organization of the United Nations based in the Hague, Netherlands.

The International Court of Justice has general subject jurisdiction, especially concerning International Law of the Sea which is not limited to the issue of maritime law and can then also decide upon the issue of maritime sovereignty based on Articles 287 and 288 of UNCLOS 1982.In resolving ICJ disputes based on applicable international law, international customs which are evidence of general practice and accepted as law, general principles which are recognized by countries that have civilization. Those entitled to submit their dispute cases are countries that are members of the case where the case is not a case at the request of individuals, nongovernmental organizations, corporations or others. ${ }^{24}$

In resolving disputes, the ICJ decision is a legal decision which is binding on the parties to the dispute. While the opinion issued by the ICJ is not a binding decision, ICJ has jurisdiction over two types of cases, the first is on contentious cases with binding decisions between countries that are parties, and has previously agreed to submit to the decision. the court, and the second is to issue advisory opinions that provide legal reasons / answers, according to questions asked in the scope of international law, but are not binding. ${ }^{25}$

Regarding disputes that have occurred in Indonesia and decided by the ICJ is a dispute over the Sipadan and Ligitan Islands between Indonesia and Malaysia in 2002 which was decided by ICJ that Sipadan and Ligitan entered into Malaysian sovereignty after 5 years the case was registered with ICJ. ${ }^{26}$ The International Court of Justice decides sovereignty over the two islands by applying the principle of effectiveness or effective control.

The International Court of Justice ensured that the British synagogue, the Malaysian occupier, had carried out effective control of this matter, as evidenced by the application and enforcement of rules relating to the collection of turtle eggs and the establishment of a nature reserve for the protection of birds that continued by Malaysia after independence. And also the construction of lighthouses by the British on the island is considered sufficient to support Malaysia's claims to the two islands.

Some ICJ decisions regarding the law of the sea since 1994 include (Aceris Law: 2015):

a) Fisheries Jurisdiction1998 (Spain v. Canada) 2001 Maritime Delimitation and Regional Inquiries (Qatar v. Bahrain)

b) Land and Maritime Boundaries2002 (Cameroon v. Nigeria: Equatorial Guinea Interventions)

\footnotetext{
${ }^{24}$ International Court of Justice. Retrieved from : https://www.icj-cij.org/en/court, Accessed on March 28, 2020.

${ }^{25}$ Julianto Jover Jotam Kalalo, 2016, Settlement of Disputes Over Cases of State Immunity through ICJ (International Court of Justice), Jurispurudence, 3 (2), p. 105

${ }^{26}$ International Court of Justice. 2002. "Sovereignty over Ligitan Island and Sipadan Island (Indonesia / Malaysia)", The Hague . Retrieved from : http://www.icj-cij.org/ docket / files / 102 / 7714.pdf.
} 
c) 2007 Territorial and Maritime Disputes in the Caribbean Sea (Nicaragua v. Honduras)

d) Regional and Maritime Disputes2012 (Nicaragua v. Colombia)

e) Maritime Restrictions2009 in the Black Sea (Romania v. Ukraine)

f) Maritime Disputes2014 (Peru v. Chile)

g) Whaling in Antarctica2014 (Australia v. Japan: New Zealand intervention)

\section{2) International Tribunal for the Law of the Sea}

International Tribunal for the Law of the Sea (ITLOS) is an important outcome for resolving maritime disputes under UNCLOS. ITLOS is based in Humburg, Germany. This Tribunal jurisdiction consists of all disputes and all applications submitted to him in accordance with the Convention (UNCLOS).

Jurisdiction owned is over all disputes related to interpretation or application of the convention, depending on the provisions of part 297 and the declaration made in accordance with Article 289 of the Convention. However Article 297 and pursuant to Article 298 do not prevent parties who agree to submit to judicial disputes that are stated in UNCLOS 1982. The court also has the right to give opinion advice by the seabed dispute room regarding legal statements that appear within the scope of the Assembly or the International Board of the Seabed Authority . As stated in Article 138 of ITLOS Rule:

"TheTribunalay also provides an advisory opinion on a legal question if this is provided by an international agency related to the purposes of the convention."

There are at least 22 cases were listed before ITLOS until now: among them, most of them "quickly released" related cases. There are only two cases of determining sea boundaries: one is the Dispute concerning the establishment of maritime boundaries between Bangladesh and Myanmar in the Bay of Bengal (Case No. 16, ITLOS) which began on December 14, 2009 and ended on March 14, 2012 and the other is the Limitation on Disputes Concerning the Maritime Boundary between Ghana and Côted' Gading in the Atlantic Ocean (Case No 23, ITLOS), which began on 3 December 2014 and ended on 23 September 2017. So, in the case of maritime boundary disputes, the position of ITLOS was not in expectation. ${ }^{27}$

\section{Comparison of Settlement through Litigation and Non-Litigation}

Dispute resolution is a matter that must be done by the parties to the dispute so that their dispute can be quickly resolved. In the UN Charter it is regulated on how to resolve the dispute, in general there are two ways, namely through peaceful means or through violence. But certaintly the peaceful way is mostly done or made a choice by the disputing parties, and between such peaceful ways can be passed by litigation (court) and non-litigation (outside the court). From the two settlement paths there are differences including:

a) Litigation

${ }^{27}$ Md. Monjur Hasan, He Jian, Md. Wahidul Alam \& KM Azam Chowdhury. Op.cit, p.94. 
If seen from the whole process, using litigation is an effective alternative in resolving disputes, especially international disputes. The judiciary will certainly be the last option when parties who have tried to settle out of court (nonlitigation). Disputes are resolved through a court of law, either the International Court of Justice or other courts of the competent authority. Certainly, the dispute will be examined by a judge in a series of trials. International justice which has quite an extensive jurisdiction is the ICJ, in which later the court has the authority to accept, examine and try as well as resolve disputes submitted to it by means of its decisions or advice.

In adjudicating a case of the International Court of Justice the decision issued must have a practical effect on the legal relations of the parties concerned, the full extent of which is 28

"'The Court's judgment must have some consequences in the sense that it can affect existing legal rights or obligations thereby removing uncertainty from their legal relations. No judgment on the merit in this case would satisfy the essentials of the judicial functions. "

The most important thing in resolving international disputes through the judiciary is the decision issued will bind the parties to the dispute, which is clearly the parties must submit to and respect the judge's decision. This is contained in article 59 of the Statute of the Court, which states that "the decision of the Court has no binding force between the parties and in respect of that particular case." From the formulation of this article, it appears that the Court does not follow the principle of stare decisis (the nature of binding precedents) as it is known in the Common Law system. The parties are given the freedom to resolve their disputes in what way, where all that is needed is an agreement of the parties to settle the case. The agreement of the parties giving and submitting their dispute to the Court does not necessarily or automatically mean that the Court will accept it. So far there are two main reasons that the Court has objected or refused to resolve the dispute submitted to it. ${ }^{29}$

Jurisdiction of the Court is limited to the state. An individual or company is outside the jurisdiction of the Court. This, of course, is the real reason at least the dispute is resolved by the Court. Usually disputes between countries submitted to the Court are disputes that are classified as large, sensitive and complex (compare with the disputed groups above). Disputes that are relatively uncomplicated, simple usually are not submitted to the Court.

b) Non-litigation

There are several ways to resolve disputes outside the court of which are negotiation, mediation, arbitration, conciliation.

(1) Negotiations, a way to settle using negotiations is the first way that will be taken when the parties to the dispute. If the parties have submitted their dispute to a certain judicial body, the process of resolving disputes through negotiations can still be carried out. ${ }^{30}$ Negotiations are carried out

\footnotetext{
${ }^{28}$ Haula Adolf, Op.cit, p. 4

${ }^{29}$ Ibid, p. 28

30 Peter Behrens, Alternative Methods of Dispute Settlement in International Economic Relations in: Ernst-Ulrich Petersmann and Gunther Jaenicke, Adjudication of International Trade Dispute in International and National Economic Law, in: Haula Adolf "Settlement of International Disputes," p. 28
} 
by parties who have an effort without involving a third party in the settlement. The disadvantage of negotiations is that when one party does not have a strong position then this party will be pressured by the party that has a position, other than that the negotiation process is also quite slow and takes a long time.

(2) Mediation, mediation is a way of peace through a third party. Like negotiations, mediation does not have specific procedures that must be taken in the implementation process. The parties are given the freedom to determine the procedure. The most important thing in mediation is the agreement of the parties in their decision whether or not to accept the proposals that have been given by the mediator.

(3) Conciliation, conciliation is a more formal dispute resolution rather than mediation. Conciliation is done through a third party which is incorporated in the conciliation commission formed by the parties. ${ }^{31}$ The commission can be institutionalized or ad hoc (temporarily) which functions to determine the terms of settlement that will be accepted by the parties, but the decision is not binding on the parties. ${ }^{32}$

(4) Arbitration, arbitration is the voluntary submission of a dispute to a neutral third party and the decision is final and binding. The selection of arbitrators is entirely in agreement with the parties, usually they choose parties who are experts on the subject matter and the main thing is neutral. Settlement using arbitration does not guarantee that the award is binding. International law does not guarantee that the losing party or dissatisfied with the decision will carry out the decision, in the sense of a reminder of the concept of pacta sunt servanda. ${ }^{33}$

\section{Conclusion}

Settlement of sea boundary disputes in Indonesia is more effective through litigation because in this path each country in dispute with Indonesia will comply with decisions made in international courts both through ITOLS and the IJC. Nevertheless there are still countries that violate Indonesia must conduct negotiations before the dispute is brought to the jurisdiction of the international court to be decided. The litigation pathway is more effective because all countries comply with the 1982 UNCLOS convention for countries that have ratified it, and most countries disputing with Indonesia have ratified it. Litigation also has legal certainty and is fair in deciding international disputes.

\section{Acknowledgments}

In the name of Allah, the Most Compassionate, the Most Merciful, the authors offer praise and thanksgiving for His presence, which has bestowed His mercy, guidance, and inayah to the author, so that he can complete scientific journals under the title Assessing the Effectiveness of Settling Indonesian Sea Border Disputes through Litigation and Non-Litigation Paths.

\footnotetext{
${ }^{31}$ Haula Adolf, Op.cit. p. 34.

${ }^{32}$ Ibid, p. 34

33JG, Merrils, 1995, International Dispute Settlement, Cambridge: Cambridge UP, p. 105
}

\section{https://journal.unnes.ac.id/sju/index.php/Islr/}


This scientific journal received a lot of help and support from various parties. For this reason, on this occasion the author greets infinite thanks to Sister Miftah Santalia, Nur Arissa Izzatiwho have helped and guided in the preparation of this journal. All parties who have supported the completion of this journal, both moral and material, especially my parents and colleagues.

Despite all that, the author is fully aware that this scientific journal is far from perfect. Therefore, with open arms the author accepts all criticism and suggestions for the perfection of this scientific journal. Finally, the authors hope that this scientific journal can provide benefits and inspiration to readers.

\section{References}

Books

Anwar, Chairul. (1995). Exclusive Economic Zone in International Law. Jakarta: Sinar Grafika.

Budiardjo, M. (2008). Fundamentals of Political Science. Jakarta: PT Gramedia Pustaka Utama.

Djalal, Hasyim. (1979). Indonesia's Struggle in the Field of Sea Law. Jakarta: Bina Cipta.

JG, Merrils. (1995). International Dispute Settlement. Cambridge: Cambridge UP

Kusumaatmadja, M. (1986). International Law of the Sea. Jakarta: Bina Cipta.

Phartiana, IW (2014). International Sea Law and Indonesian Sea Law. Bandung: Yrama Widya Publisher.

Prijanto H. (2007). International Law of the Sea. Malang: Bayumedia Publishing.

Soerjono and Abdurahman, H. (2003). Legal Research Methods. Jakarta: Rineka Cipta.

Soekanto Soerjono and Mamudji Sri. (1990). Normative Legal Research. Jakarta: Rajawali Press.

Tirtamulia T. (2011).Zona-Zona UNCLOS 1982. Surabaya: Brilliant International.

\section{Journals}

Behrens, Peter. "Alternative Methods of Dispute Settlement in International Economic Relations," in: Ernst-Ulrich Petersmann and Gunther Jaenicke, Adjudication of International Trade Dispute in International and National Economic Law, in: Haula Adolf "International Dispute Resolution"

E. Doukakis. (2014). Associate Professor, National Technical University Athens Visiting Professor, Cyprus University of Technology, East Meded Symposium, Limasal, Cyprus. p.3. http://www.oceanography.ucy.ac.cy/eastmed/wpcontent/uploads/2014/11/D3S1-Doukakis.pdf

Hassanudin Z. Abidin, et al. (2005). Geodetic Datum Indonesia-Singapore Maritime Boundary: Status and Problems, PROC. ITB Science \& Tech Bandung. 37 A (1). p.23.

Ismi Yulia Masfiani L., Tri Setyawanta R, Nanik Trihastuti. (2016).Settlement of Maritime Border Disputes Between Costa Rica and Nicaragua in the Caribbean Sea and Pacific Ocean In the 1982 UNCLOS Perspective, Diponegoro Law Journal. 5 (3).p.5. Retrieved from http://www.ejournals1.undip.ac.id/index.php/dlr/

Kalalo, JJJ (2016). Settlement of Disputes Over Cases of State Immunity through ICJ (International Court of Justice), Jurispurudence.3 (2). p.105. 
Maulidya Yuseini, et al (2018). Settlement of Sea Disputes Between Indonesia and Malaysia in the Malacca Strait Area According to International Sea Law, Journal of the Law Lantern: Negrei University, Jember. 5 (3). p.459.Doi: 10.19184 / ejlh.v5i3.7731

Md. Monjur Hasan, He Jian, Md. Wahidul Alam \& KM Azam Chowdhury.(2019). Protracted maritime boundary disputes and maritime laws, Journal of International Maritime Safety, Environmental Affairs, and Shipping. 2(2).p.89.

Merilin LI Thomas.(2013). Juridical Review of Dispute Resolution Concerning the Determination of the State Sea Territory (Case Study of the Ambalat Dispute Between Indonesia and Malaysia, Journal: Lex et Societatis. 1(2). p.160.

Natalia, K. (2013). Resolution of Boundary Issues Between Indonesia and Malaysia in the Malacca Strait Waters Viewed from UNCLOS 1982, UNESA Student Scientific Journal. 2 (2).

PCA (2014). The Bay of Bay of Bengal Maritime Boundary Arbitration between the People's Republic of Bangladesh and the Republic of India.

Phan, HD and Nguyen, LN (2017). The South China Sea Arbitration: Bindingness, Finality, and Compliance with UNCLOS Dispute Settlement Decissions, Asian Journal International Law. p.2.

Prescott, V.(2004). Maritime Political Boundaries of the World, Martinus Nijhoff Publisher.p.245.

Ummi Yusnita.(2018).Settlement of Sea Border Disputes Between Indonesia and Malaysia in the Perspective of International Law, Journal of Legal Development. 7 (1). P.101.

Vinata, RT (2017). Harmonization of Equidistance Line Priciple and Media Lline Principle in Setting Sea Boundaries, Journal of Legal Perspective. 17(2). p.218.

\section{Online/World Wide Web}

Aceris Law. (2015). Law of the Sea Dispute Settlement Mechanism, International Arbitration Attorney Network. Retrieved from https://www.internationalarbitration-attorney.com/lawof-the-sea-dispute-settlement-mechanism/, Accessed on April 30 2020).

Callistasia, Wijaya. (2019). The Indonesia-Vietnam conflict is threatened to repeat itself as long as there is no Exclusive Economic Zone agreement.Retrieved from https://www.bbc.com/indonesia/indonesia-48103607, Accessed on March 282020.

International Court of Justice. (2002). Sovereignty over Ligitan Island and Sipadan Island (Indonesia / Malaysia), The Hague. Retrieved from : http://www.icj-cij.org/ docket / files / 102 / 7714.pdf.

International Court of Justice. Retrieved from : https://www.icj-cij.org/en/court , Accessed on March 282020.

International Tribunal for the Law of the Sea. Retrieved from : https://www.itlos.org/en/the-tribunal, Accessed on March 28, 2020.

International Tribunal for the Law of the Sea. Retrieved from : https://www.itlos.org/jurisdiction/competence/ Accessed on March 28, 2020.

Ministry of Foreign Affairs Republic of Indonesia. Retrieved from https:// kemlu.go.id/portal/id/read/389/berita/indonesia-dan-filipinahave-resolve-ratification-program-batas-zee, Accessed on April 302020.

\section{https://journal.unnes.ac.id/sju/index.php/IsIr/}


Patmasari, Artanto, and Rimayanti. The Latest Development of Indonesia's Maritime Border with Neighboring Countries: Center for Boundary Mapping. Jakarta: Geospatial Information Agency.

Poskotanews. (2019). Bakamla RI Discusses Indonesia-Vietnam ZEE Limit. Retrieved from https://poskotanews.com/2019/09/25/bakamla-ri-bahasbatas-zee-indonesia-vietnam, Accessed on March 282020.

\section{Laws and Regulations}

United Nations Convention (UNCLOS) 1982

The Act Number 5 of 1983 concerning Indonesia's Exclusive Economic Zone. RI State Gazette of 1983 Number 44 